\title{
STRIKING THE BALANCE: CONGRESS AND THE PRESIDENT UNDER THE WAR POWERS RESOLUTION*
}

\author{
Cyrus R. VANCE $\dagger$
}

\section{INTRODUCTION}

The War Powers Resolution ${ }^{1}$ once again has gained center stage in the foreign policy debate. In Lebanon, Grenada, and Gentral America, significant numbers of American troops have been deployed within the past year. These deployments, each of which was ordered by the President on his own authority without prior consultation with the Congress, have stirred a new debate about presidential war-making powers.

The debate centers on the question of whether, in this nuclear age, Congress should have a greater voice in any decision to deploy U.S. forces where hostilities exist or are imminent. Such decisions, in my opinion, should be based on the collective judgment of Congress and the President. This is in accord with both the intention and spirit of the Constitution. Historically, our Presidents have taken the initiative on matters of war or peace, but I am heartened that Congress has recently shown a new determination to fulfill its proper constitutional role. The War Powers Resolution, enacted in 1973, embodies that determination.

This afternoon I will discuss several aspects of that Resolution: its historical background, its constitutionality, whether it reflects sound policy, its effectiveness, and whether it needs to be strengthened.

\section{Historical Perspective}

Through much of our history, the constitutional power of Congress "to declare War" has not prevented Presidents from sending our armed forces into hostilities, or situations where hostilities were imminent, without the prior approval of Congress. One scholar has identified 199 U.S. military engagements overseas between 1798 and 1972

* Originally delivered as the Owen J. Roberts Memorial Lecture at the University of Pennsylvania Law School on February 23, 1984.

t Partner, Simpson Thacher \& Bartlett. A.B. 1939, Yale College; LL.B. 1942, Yale Law School. Mr. Vance served as Secretary of State in the Carter Administration from 1977 to 1980 . The author wishes to acknowledge with gratitude the helpful advice and assistance of his friends and colleagues Thomas H. Bell, John L. Kerr, Jr., and Richard W. Petree, Jr.

150 U.S.C. $\$ \S 1541-1548$ (1982). 
that occurred without a declaration of war. ${ }^{2}$ Historically, Presidents have acted and the Congress has acquiesced. The incidents ring out from the pages of history. To name but a few: Jefferson and the Barbary pirates; Polk and Mexico; McKinley and the Boxer Rebellion; Teddy Roosevelt and Panama; Taft, Wilson, and Coolidge in Nicaragua, Haiti, and the Dominican Republic.

And the history is not so old. Before the United States officially entered World War II, President Franklin Roosevelt, without consulting Congress, ordered the occupation of Greenland and Iceland and directed the Navy to protect British merchant shipping in the North Atlantic. President Truman committed the U.S. to the Korean War on the recommendation of the United Nations Security Council rather than pursuant to a congressional mandate. President Kennedy ordered a naval blockade of Cuba without congressional endorsement. In 1965 President Johnson dispatched 22,000 U.S. troops to the Dominican Republic without congressional approval. Notwithstanding Congress's passage of the Gulf of Tonkin Resolution in August of $1964,{ }^{3}$ President Johnson viewed his orders to bomb North Vietnam the following February and to land the first American combat troops in South Vietnam a month later as being based on his authority alone. Johnson said in 1967, "We stated then, and we repeat now, we did not think the [Gulf of Tonkin] Resolution was necessary to do what we did and what we're doing."4

President Nixon enlarged upon President Johnson's view of presidential war-making powers. During the latter stages of the war in Vietnam and the invasion of Cambodia, the President asserted that his constitutional role as Commander-in-Chief conferred on him almost unlimited discretion over the deployment of troops. ${ }^{5}$

Vietnam, however, marked the turning of the tide of two centuries of gradually expanding Presidential war-making power. Galvanized by domestic divisions about the war's aims, its length, its human and material costs, and its failure to secure our stated aims, Congress began to limit the President's power to wage war. In 1969 the Senate passed a resolution declaring that a national commitment of U.S. forces could

${ }^{2}$ See Emerson, War Powers Legislation, 74 W. VA. L. Rev. 53, 88-110, 367-68 (1972) (orignially enacted as Pub. L. No. 93-148, 87 Stat. 555 (1973)).

3 Gulf of Tonkin Resolution, Pub. L. No. 88-408, 78 Stat. 384 (1964).

4 N.Y. Times, Aug. 19, 1967, at 10, col. 1, 6. Cf. Meeker, The Legality of United States Participation in the Defense of Viet-Nam, 54 DEP'T ST. BuLL. 474, 484-85 (1966).

'See, e.g., War Powers Legislation: Hearings on S. 731, S.J. Res. 18 and S.J. Res. 59 Before the Senate Comm. on Foreign Relations, 92d Cong., 1st Sess. 485 (1972) (remarks of Sec'y of State William Rogers). 
arise "only from affirmative action taken by the executive and legislative branches of the United States Government by means of a treaty, statute, or concurrent resolution of both Houses of Congress specifically providing for such commitment."B

In 1970 and 1971 the House passed bills that would have required the President to report to Congress after placing troops in combat." These House bills were modest. They did not assert congressional power to begin or end military commitments. However, the Senate refused to pass the House measures. In 1971 the Senate countered with a bill entitled the "War Powers Act," which for the first time attempted to enumerate the President's war powers. ${ }^{8}$ The War Powers Act died in conference, but the following year both the House and Senate passed measures that went to a conference committee in July of 1973. The conference bill, called the "War Powers Resolution," was reported out on October 4, 1973, and was passed with bipartisan support over President Nixon's veto on November 7, 1973.

\section{ANalysis of Statutory Text}

Section 2(a) of the War Powers Resolution states in unambiguous terms its legislative purpose, which was to "insure that the collective judgment of both the Congress and the President will apply to the introduction of United States Armed Forces into hostilities, or in situations where imminent involvement in hostilities is clearly indicated by the circumstances, and to the continued use of such forces in hostilities or in such situations."

Section 2(c) describes the President's constitutional powers to use armed force. The Resolution acknowledges that the President may introduce armed forces into hostilities or into situations where hostilities are imminent (1) when Congress declares war, (2) when Congress legislates specific authority to act, or (3) when the United States or its armed forces are under attack. ${ }^{10}$ I believe that this provision is a nonbinding and non-exhaustive statement of the President's powers. I will have more to say on this later.

Section 3 directs the President to consult with Congress-and I

- S. Res. 85, 91st Cong., 1st Sess., 115 Cong. Rec. 17,245 (1969).

7 See H.R.J. Res. 1355, 91st Cong., 2d Sess. (1970); H.R.J. Res. 1, 92nd Cong., 1st Sess. (1971), reprinted in War Powers Legislation: Hearings Before the Subcomm. on National Security Policy and Scientific Developments of the Comm. on Foreign Affairs, 92d Cong., 1st Sess. iii (1971).

8 See S. 2956, 92nd Cong., 2nd Sess., 118 Cong. Rec. 12,611 (1972).

- 50 U.S.C. $\$ 1541$ (a) (1982).

${ }^{20}$ See id. § 1541(c). 
emphasize the word "consult"- "in every possible instance" before introducing U.S. forces "into hostilities or into situations where imminent involvement in hostilities is clearly indicated by the circumstances."11 Section 3 also requires the President to consult regularly with Congress following any introduction of forces until they have been disengaged. ${ }^{12}$

Section 4 requires that whenever U.S. forces are deployed, in the absence of a declaration of war, the President must in certain instances report to Congress within 48 hours after their deployment and periodically thereafter. ${ }^{13}$ Those instances are when U.S. forces are introduced (1) into hostilities or imminent hostilities; (2) into the territory, air space, or waters of a foreign nation, when equipped for combat (except when solely for the supply, replacement, repair, or training of forces); or (3) in numbers that substantially enlarge U.S. forces equipped for combat already located in a foreign country. ${ }^{14} \mathrm{I}$ emphasize that the second and third circumstances just mentioned are not dependent on there being actual or even imminent hostilities.

Section 5 provides that, no later than sixty days after a report is required under section 4, "the President shall terminate any use of United States Armed Forces with respect to which such report was submitted"16 unless Congress specifically authorizes the operation to continue or "is physically unable to meet as a result of an armed attack upon the United States."16 The sixty-day period can be extended for an additional thirty days if the President certifies to Congress that additional time is needed to safeguard the prompt removal of our forces. ${ }^{17}$

Section 5(c) contains the important provision that whenever U.S. forces "are engaged in hostilities outside the territory of the United States, its possessions and territories without a declaration of war or specific statutory authorization, such forces shall be removed by the President if the Congress so directs by concurrent resolution."18 Section 5(c) is, in effect, a potential congressional veto over any presidential use of our armed forces outside the United States even within the sixty or ninety-day period described above.

Sections 6 and 7 contain procedural rules governing House and

11 Id. § 1542.

12 See id.

13 See id. § 1543.

$14 I d$. $\S 1543$ (a). The report must be submitted to the Speaker of the House of Representatives and to the President Pro Tempore of the Senate in writing within 48 hours of any introduction of forces. $I d$.

1s Id. § 1544(b).

${ }_{16} I d$.

17 Id.

18 Id. $\S 1544(\mathrm{c})$. 
Senate actions in authorizing the use of forces beyond the sixty or ninety-day limit and in terminating the use of forces in accordance with section 5(c) ${ }^{19}$ In both cases, matters arising under the War Powers Resolution are given priority in the legislative calendar.

Section 8 provides that no authority for the use of troops shall be inferred from any provision of law unless the law indicates a specific intent to grant such authority within the meaning of the Resolution. ${ }^{20}$ Section 8 specifically includes within its scope defense appropriations. By the same token, no authority for the deployment of troops is to be inferred from any existing or future treaty, unless Congress passes implementing legislation granting specific authority. ${ }^{21}$

Finally, section 8(d) crystallizes the essential constitutional question about the extent of presidential war-making powers. It declares that nothing in the resolution "is intended to alter the constitutional authority of the Congress or of the President, or the provisions of existing treaties," or "shall be construed as granting any authority to the President with respect to the introduction of United States Armed Forces... . which he would not have had in the absence of this joint resolution].

\section{Constitutional Basis}

The War Powers Resolution raises a number of important and thorny constitutional issues. While the issues are too complex to be analyzed in depth here, I wish to explain briefly why I believe the Resolution to be constitutional. At the outset, I would emphasize that the War Powers Resolution was enacted to deal with constitutional issues that fall in a "twilight zone"- a zone that Professor Louis Henkin has called an area of concurrent power. ${ }^{23}$ The Constitution does not establish a clear, comprehensive "system" for the conduct of foreign and military affairs. Some powers are allocated to Congress; others are allocated to the President. But many important foreign affairs powers and war powers are not expressly allocated, and even the extent of those that are allocated is unclear.

Congress is given the basic power to declare war. It also is given the power to raise and support armies, to provide and maintain a navy, to make rules for the government of military forces, to lay taxes and

19 See id. $\$ \S 1545,1546$.

${ }^{20}$ See id. § 1547(a)(1).

21 See id. § 1547(a)(2).

22 Id. $\S 1547(\mathrm{~d})$.

2s See L. Henkin, Foreign Affairs and the Constitution 104-08 (1972). 
provide for the common defense, to appropriate moneys, and to make all laws necessary and proper for the executive powers vested in the federal government. ${ }^{24}$

The President, on the other hand, is given the power to act as Commander-in-Chief, to make treaties and appoint envoys with the Senate's consent, and to exercise the "executive power" of the federal government. ${ }^{25}$ The President is also obligated to execute faithfully the laws of the nation, including our defense commitments under treaties.

Three points are apparent from this list of enumerated powers. First, the roles of Congress and the President in foreign and military affairs do not fit neatly into the classic concept of the separation of legislative and executive powers. Instead, the area is one of shared and overlapping responsibilities as each branch participates in both the formulation and implementation of policy. Second, the allocation of powers is piecemeal and incomplete. In particular, the issue of who possesses authority to use armed forces short of declared war is unresolved. The practical effect of this is to leave the issue to be resolved in the political arena. The combination of overlapping responsibilities and unresolved questions of authority makes establishment of effective means of cooperation and coordination especially important to the effective conduct of foreign and military policy. Third, it is worth noting that the framers of our Constitution lived in a very different world. At that time the United States was a small nation with limited capability for projecting its forces beyond its shores and without the daily and diverse contacts with the outside world that now affect our daily lives and security. The constitutional allocation of powers relating to foreign policy and national security, which today strikes us as piecemeal, was probably adequate to meet the needs of our nascent Republic. In today's complex world, however, this will no longer do. It is against this background of constitutional ambiguity and the resulting need for a mechanism to mediate the shared exercise of unallocated, but essential, constitutional powers that the War Powers Resolution must be evaluated.

From a constitutional standpoint the most controversial provisions of the Resolution are the termination provisions of section 5 requiring congressional authorization for the deployment of troops into hostilities for longer than sixty days and the removal of troops from hostilities at any time upon passage of a concurrent resolution.

The principal objection voiced to these provisions is that they impinge upon the President's exercise of the inherent war-making powers

24 See U.S. Const. art. I, § 8.

${ }^{25}$ See id. art. II, $\S \S 1,2$. 
he possesses by virtue of being vested with the executive power of the federal government and his designation as Commander-in-Chief. This objection, I believe, mistakes the nature and purpose of the statute. The purpose of the Resolution is not to define or modify the constitutional powers of the President. That approach was considered in the Senate version of the bill and was rejected. ${ }^{26}$ Indeed, section 8 (d) expressly states that nothing in the Resolution alters the constitutional authority of the President. ${ }^{27}$ Rather, the purpose of the Resolution was to establish a procedure through which Congress and the President can exercise their respective powers.

The Resolution does not deny that the President possesses some inherent war-making powers. Judicial precedent and constitutional scholars suggest that these include the powers to repel actual or imminent attacks upon the country or its armed forces ${ }^{28}$ and possibly to rescue U.S. citizens abroad. ${ }^{28}$ Although the President does have some inherent war powers, they are not unlimited and arguably do not extend beyond the circumstances just mentioned.

With the exception of the three specific instances just described, any presidential exercise of war-making powers without congressional approval raises the question whether the President possesses the authority to act unilaterally. The War Powers Resolution establishes a procedure by which Congress can express its institutional judgment on this question. Consequently, to object to the statute's termination provisions on the ground that they may be applied to situations where the President has acted pursuant to his inherent powers is to beg the crucial question of authority. If Congress vetoed the President's commitment of troops into hostilities by means either of a concurrent resolution or a failure to authorize an extension under the sixty-day cutoff provision, it would indicate that in Congress's judgment the President lacked authority for his actions or that Congress is asserting its inherent authority to terminate hostilities. This judgment may be right or wrong. But a statute that establishes a procedural mechanism for such congressional expression is clearly a valid exercise of Congress's constitutional power to make all laws "necessary and proper" for the execu-

${ }^{28}$ See S. 2956, 92d Cong., 2d. Sess. (1972).

27 See 50 U.S.C. $\S 1547$ (d) (1982).

${ }^{28}$ See, e.g., The Prize Cases, 67 U.S. (2 Black) 635 (1863); Emerson, The War Powers Resolution Tested: The President's Independent Defense Power, 51 NoTRE Dame LAw. 187 (1975).

${ }^{29}$ See, e.g., Durand v. Hollins, 8 F. Gas. 111 (C.C.S.D.N.Y. 1860) (No. 4186); Emerson, supra note 28, at 192. For a summary of Congress's view of this issue, voiced after the Mayaguez incident, see Comm. ON Foreign Affairs, 97TH Cong., 2D Sess., The War Powers Resolution 216 (Comm. Print 1982). 
tion of powers constitutionally vested in the federal government.

Another objection to the termination provisions is that, under the sixty-day cutoff provision, legal consequences attach to congressional indecision. It is one thing, opponents argue, for Congress to limit the President through actions affirmatively taken. It is another, however, to permit the failure of Congress to act to constitute a congressional veto of presidential actions. Again, however, this objection misconstrues the provision in question. The sixty-day cutoff provision must be evaluated in the context of the provisions of sections 6 and 7 assuring priority consideration of any resolution introduced pursuant to sections 5(b) and (c). Given the gravity of the subject matter and the provisions for priority in the legislative calendar, it is difficult to believe that Congress would fail to address the subject of extending our involvement in hostilities. Furthermore, if, after congressional consideration of our participation in a foreign conflict, a majority vote in favor of continued deployment of forces cannot be obtained from Congress, it seems right that our forces should be withdrawn. Engagements lasting longer than sixty or ninety days should have the support of a majority of Congress.

Third, it is claimed that the Supreme Court's recent decision in Immigration $\mathcal{E}$ Naturalization Service $v$. Chadha ${ }^{30}$ invalidates the concurrent resolution provision of section 5(c). In Chadha the Court struck down a one-house legislative veto of a deportation suspension on the grounds that it violated the Constitution's presentment and bicameral requirements. ${ }^{31}$ Although the language in Chadha is broad and its scope unclear, I do not conclude that the decision invalidates a congressional veto in the context of action under the War Powers Resolution. Not only is Chadha distinguishable on the facts both as a one-house veto and as a matter arising in a domestic context, but its rationale does not conflict with section 5(c) of the Resolution.

The Chadha Court was concerned that the principle of the separation of powers would be undermined by the delegation of broad, discretionary lawmaking authority to the executive branch, coupled with congressional control over the administration of such laws by means of a legislative veto. ${ }^{32}$ In contrast, the legislative veto contained in the War Powers Resolution does not undermine the principle of separation of powers. It does not accompany a delegation of lawmaking authority to the executive branch, and it is not an attempt to interfere with the administration of the laws. Rather, it is an attempt to reassert the authority of Congress in an area where legislative and executive functions are

so 103 S. Ct. 2764 (1983).

31 Id. at $2782-88$.

32 See id. at 2784 . 
not susceptible of sharp delineation and where powers tend to be shared rather than separated. In sum, although the issue is not free from doubt, I believe the better view is that the legislative veto provision of the Resolution should survive scrutiny under Chadha.

The Resolution has also been challenged as violative of our treaty commitments. Section $8(\mathrm{a})(2)$ provides that presidential authority to introduce armed forces into hostilities shall not be inferred from any treaty unless the treaty specifically states that it confers such authority. $^{33}$ This provision at first glance appears to be an alteration of the terms of such treaties as the North Atlantic Treaty ${ }^{34}$ and the Rio Pact, ${ }^{38}$ both of which provide that an attack against one party to the treaty shall be considered an attack against all and that each member shall come to the assistance of the state attacked.

The response to this objection is that such treaties do not purport to, and indeed cannot, confer greater war-making authority upon the President than he otherwise possesses. The legislative histories of such treaties are explicit: they are not intended to delegate to the President the power to go to war. ${ }^{38}$ Our treaty commitments merely obligate the United States government-both Congress and the Presidentpromptly to take the actions it deems necessary to restore and maintain the security of the member states.

Finally, although the consultation and reporting requirements of sections 3 and 4 have generated repeated disputes over presidential compliance, their constitutional validity is not open to serious question. Congress cannot effectively or wisely exercise its war-making powers under the Constitution unless it possesses the knowledge necessary to act. Thus, the Resolution's consultation and reporting requirements are an appropriate exercise of Congress's power to make all laws that are necessary and proper for executing its constitutionally vested powers.

\section{The War Powers Resolution in Practice}

Between the passage of the War Powers Resolution in 1973 and the end of last year, Presidents Ford, Carter, and Reagan reported a total of ten military actions to Congress. Those reports covered the

ss See 50 U.S.C. $\S 1547(\mathrm{a})(2)$ (1982).

st April 4, 1949, art. V, 63 Stat. 2241, 2244, T.I.A.S. No. 1964, 34 U.N.T.S. 243, 246.

ss Rio Treaty, Sept. 2, 1947, art. iii, 62 Stat. 1681, 1700, T.I.A.S. No. 1838, 21 U.N.T.S. 77, 95.

s8 See, e.g., Senate Foreign Relations Comm., Documents Relating to the North Atlantic Treaty, S. Doc. No. 48, 81st Cong., 1st Sess. 11 (1949) (letter of Sec'y of State Dean Acheson: "Under our Constitution, the Congress alone has the power to declare war."). 
evacuations of Danang, Phnom Penh, and Saigon; the recapture of the "Mayaguez"; the aborted mission to rescue hostages in Iran; the participation of U.S. forces in the Sinai and Lebanon multinational peacekeeping forces; the sending of AWAC's and fighter planes to Chad; and the invasion of Grenada. It is striking that in none of these cases has the President adequately consulted in advance with Congress as contemplated by section 3 of the War Powers Resolution. A brief review of three of these cases reveals that a cardinal objective of the War Powers Resolution-its involvement of Congress in consultations with the President before the President introduces forces-is not being realized in practice.

On May 12, 1975, the merchant ship Mayaguez was seized by Cambodian forces in the Gulf of Siam. ${ }^{37}$ At 6:20 a.m., Washington time, on the morning of May 13, U.S. aircraft fired warning shots across the bow of the Mayaguez to prevent the ship from being moved to the Cambodian mainland. On May 13 and May 14, U.S. fighter planes sank three Cambodian gunboats ready to move the Mayaguez's U.S. crew to the mainland. Later in the morning of the 14th the destroyer escort "Holt" arrived on the scene, and that afternoon President Ford ordered U.S. forces to assault Kho Tang Island where the crew was believed to be imprisoned. The assault began that evening and was followed three hours later by the heavy bombing of Ream airfield on the mainland. Fifteen marines were killed in combat on Kho Tang Island, and another twenty-three marines died in a helicopter crash in Thailand related to the assault.

At about 7:00 p.m. on the evening of May 13, more than twelve hours after the first warning shots were fired by U.S. forces, a White House congressional liaison officer began to telephone congressional leaders to inform them of the situation. These calls, which were made over approximately an hour and a half, have been described by their recipients as a perfunctory notification of U.S. actions. They were not a genuine attempt to consult with the leadership. Senate Majority Leader Mansfield reported later: "I was not consulted. I was notified after the fact about what the Administration had already decided to do."38 The White House liaison officer himself reported that he had "been given a

${ }^{37}$ For this account I am indebted chiefly to Franck, After the Fall: The New Procedural Framework for Congressional Control over the War Power, 71 AM. J. InT'L L. 605, 616-21 (1977) and The Reports of President Ford to House Speaker Carl Albert reprinted in Subcomm. on International Security and Scientific Affairs of the House Comm. on Foreign Affairs, 98th Cong., 1st Sess., The War Powers Resolution: Relevant Documents, Correspondence, Reports 42, 45-46 (Comm. Print 1983) [hereinafter cited as WAR Power Documents].

${ }^{38}$ N.Y. Times, May 16, 1975, at 15, col. 1, 2. 
prepared statement to read to the Senators on what amounted to a fait accompli." meet directly with the President until the President convened the first of a series of meetings with the congressional leadership in the Cabinet Room at 6:40 p.m. on May 14, half an hour before the Kho Tang assault began. The President's formal report to Congress on the operation was received on Capitol Hill after the operation was completed.

The mission to rescue the Americans taken hostage on November 4, 1979 in Iran is another case in point. Plans for the mission were laid in advance of its execution, including special training of personnel and positioning of equipment. But there was no prior consultation with members of Congress concerning the planned rescue attempt. There were those in the administration who favored consulting congressional leaders in accordance with section 3 of the War Powers Resolution before our units were set in motion. However, concerns for secrecy prevailed. The mission was launched at 10:30 a.m. on April 24, 1980, Washington time, and it was aborted late in the afternoon of the same day. Only Senator Robert Byrd was notified of the mission shortly in advance, and that notification was at best sketchy. Other congressional leaders were first notified after the fact by telephone of the mission and its failure very late in the evening of April 24 and into the early morning hours of April 25. The President's formal report to Congress was delivered on April 26, 1980, within forty-eight hours of the time at which our units first entered Iranian air space but well after the rescue team had been withdrawn. ${ }^{40}$

Finally, a third case in point is the recent invasion of Grenada. In response to a breakdown of law and order beginning on October 12, 1983, the Organization of Eastern Caribbean States (the "OEGS") met in emergency session on October 21 to consider the threat posed to the peace and security of the region by the situation in Grenada. According to the President's formal report to the Congress, filed on October 25, $1983,{ }^{41}$ the OECS then asked the United States to provide U.S. forces for an expedition to restore order in Grenada. The President also reported that he had authorized our forces' participation in the OEGS "collective security force" to rescue American citizens whose safety was allegedly threatened. At 5:00 a.m. on October 25, Washington time,

so Id.

10 Report dated April 26, 1980 from President Jimmy Carter to Hon. Thomas P. O'Neill, Speaker of the House of Representatives, reprinted in WAR POWER DocuMENTS, supra note 37 , at $47-49$.

41 Report dated October 25, 1983 from President Ronald Reagan to Hon. Thomas P. O'Neill, Speaker of the House of Representatives, reprinted in War POWER Documents, supra note 37 , at 84-85. 
approximately 1,900 U.S. Army and Marine Corps troops began landing in Grenada, supported by U.S. Navy and Air Force units totaling approximately 6,000 personnel. So far as I am aware, there was no consultation with members of Congress prior to deployment. Only during the evening of October 24, 1983 did the President notify the congressional leaders that the invasion would begin early the next morning.

\section{War Powers Resolution as Policy Process: RECOMMENDATIONS FOR AMENDMENT}

Ten years after the War Powers Resolution was passed, it continues to influence our government's policy-making processes. Some of its effects were intended; others were not. Some of its goals have been achieved; others have not. Wary of the time limit on the commitment of troops unauthorized by Congress and of the congressional veto provisions of section 5(c), a President contemplating armed action must weigh in advance the likely political reaction. The Resolution reinforces presidential self-restraint and serves as a constant reminder that policies involving the use of force overseas must garner support beyond the short-term.

There is one important aim, however, that the War Powers Resolution has singularly failed to achieve. That aim is to require the President to consult with Congress "in every possible instance" before introducing forces into hostilities or into situations where hostilities are imminent. The historical instances cited earlier illustrate that Presidents have failed to consult meaningfully with Congress or even the congressional leadership about actions that could lead to involvement in hostilities abroad. In short, the goal that the President and Congress should form a "collective judgment" about the wisdom of such actions has not been realized. That goal, it seems to me, is a contemporary reaffirmation of the Framers' conviction that, while sometimes awkward and inconvenient, a system of political principles including especially "separation of powers" and effective "checks and balances" is a necessary precaution against the abuse of unfettered power in the hands of any one individual.

I believe that the "consultation" required by the War Powers Resolution means, first, that the congressional leadership should be given all information about a planned action that is material to a judgment about its advisability; second, that the congressional leadership should receive that information sufficiently in advance of the planned action to permit a reasonable opportunity to absorb the information, consider its implications, and form a judgment before irrevocable decisions are 
made by the President; and third, that the congressional leadership should have a real opportunity to communicate its views to the President or at least to his closest advisors.

As I reflect on my own experiences in government, the prudence and practicality of the consultation requirement are clear. Serving in a number of Department of Defense posts under President Johnson, I was involved in decisions about the conduct of the Vietnam War. There were a relatively small number of officials making these decisions. All of us kept in close touch with each other, sharing information, reading each others' memoranda, and responding to problems raised or views presented by other members of that group. President Johnson drew his advisors closely around him and took his counsel almost entirely from them. Looking back on that period now, I am struck by how seldom the President, or even his closest advisors, were exposed to the views of experienced outsiders who owed no special deference to the President and who were not, as we were, enmeshed in the day-to-day problems of the war. A fresh, and possibly larger, perspective on our policies might have emerged from such exchanges.

I think also of the Iranian hostage crisis and the failed rescue mission. For reasons I have discussed elsewhere, ${ }^{42}$ I entertained grave doubts about the wisdom of the rescue mission. There were some within the administration who shared these doubts. Within the administration, these doubts did not prevail. I believe that if the President had, as I had hoped, consulted in advance with key members of Congress about the rescue mission, some of them would have expressed reasonable doubts that could have affected the President's decision.

Presidents are served by officials who, for a variety of understandable reasons, sometimes find it difficult to express frank and forceful disagreement with the President's views. Presidents, despite themselves, sometimes have difficulty separating national security considerations from domestic political considerations in assessing proposed military actions. And Presidents, mired in the executive responsibilities of government, sometimes lose touch with the tide of domestic political opinion. The unadorned views of wise individuals outside the executive branch can play an important and useful role.

In my view, the War Powers Resolution is sound in concept. With minor modification, it could more effectively achieve its goal of requiring genuine consultation between the President and Congress. I have four specific recommendations.

First, I would add a statutory definition of the term "consult" as it

42 See C. VAnce, Hard Choices 407-11 (1983). 
is used in section 3 of the Resolution. The definition would make clear that what is required is the timely sharing of information and views among the President and the congressional leadership concerning a proposed deployment. I favor a definition along the lines originally proposed by Senator Eagleton, which would require the President to "discuss fully and seek the advice and counsel"43 of a defined group of congressional leaders. Drawing on my own experience as Secretary of State during the Iranian hostage crisis, during which my deputy, Warren Christopher, and I had regular and full consultations with the congressional leadership several times a week, I believe that useful and effective communication between these two branches of our government is possible. In my opinion, the group of congressional leaders to be consulted should include the Majority and Minority Leaders of both houses, the Speaker of the House of Representatives, and the Chairpersons and ranking minority members of the Armed Forces and Foreign Affairs committees of both houses.

I do not share the judgment of those who argue that genuine consultation is not feasible because congressional leaders may be unavailable during a crisis, because they will breach the secrecy on which an operation's success may depend, or because they will merely respond to the President's plans in terms of partisan politics. My experience has persuaded me that such fears are unfounded. A group of leaders such as I have suggested will almost always be within reach of the President and will keep confidences. Moreover, in my experience partisanship is not the characteristic response of congressional leaders whom the President takes into his or her confidence on high matters of state. As I have observed it, on those occasions each leader thinks for himself or herself with the best interests of our nation in mind and responds accordingly.

In addition to defining "consultation," I would make two further amendments to the Resolution, both designed to broaden the category of cases in which the President is required to consult. Presidents have often avoided the prior consultation obligation of section 3 by construing planned military actions as not involving "hostilities" or as not being "situations where imminent involvement in hostilities is clearly indicated by the circumstances." The Danang, Phnom Penh, and Saigon evacuations and the Grenada invasion, for example, were all styled as humanitarian rescue or evacuation operations rather than as the introduction of troops into potentially "hostile" situations.

I would specifically make the section 3 consultation obligation ap-

1s S. 1790, 94th Gong., 1st Sess. (1975). Senator Eagleton's latest amended version, however, does not include such a provision. See S. 1906, 98th Cong., 1st Sess., 129 Gong. Rec. 12,345 (1983) (introduced with Senators Stennis and Cranston). 
plicable to all of the actions now listed as reportable events under section 4(a)(1), namely, (1) the introduction of forces into hostilities or imminent hostilities, (2) the introduction of forces into foreign territory; air space, or waters when such forces are equipped for combat, and (3) the introduction of forces in numbers that substantially enlarge U.S. forces equipped for combat that are already in a foreign country.

I would also support the suggestion others have made that section 4(a)(1)'s recitation of reportable events be amended to add the requirement that the President consult before and report after introducing U.S. forces "into any situation in which there is armed conflict." Whether an action is subject to consultation and reporting should not turn on whether other parties to an existing conflict take it on themselves to attack U.S. forces when our forces are placed in their midst. No narrow interpretation of our forces' mission should disguise the fact that there are hostilities and that our forces have been introduced into those hostilities, if only by physical proximity.

Finally, I would support an amendment designed to withhold funds from any presidential use of force that lacks congressional authorization under the War Powers Resolution. Because the Constitution's allocation of war powers is uncertain and because Presidents have been careful to preserve what they consider an executive prerogative by avoiding any express recognition of Congress's power under the Resolution to restrict presidential uses of force, it is not inconceivable that in some future dispute over the use of our forces, a President might choose to ignore the expiration of the sixty or the ninety-day time limit on unauthorized uses of force, or even a concurrent resolution of Congress calling for the termination of our forces' involvement within that period. In such a situation, the President might obtain the funds necessary for continued operations from any number of appropriations available to the military generally and thereby thwart Congress's restriction. To avoid such an impasse and to avoid placing Congress in the position of having to cut off funds for the support of forces already in the field, Presidents should know before they commit our forces that funds for those troops and their operations will only be available if congressional authorization for their deployment is obtained in accordance with the provisions of the War Powers Resolution. I would therefore recommend that the Resolution be amended to provide that, notwithstanding any other law, no funds made available under any law may be obligated or expended for any use of United States forces prohibited by section 5(b) of the Resolution or by a concurrent resolution of Congress

14 Franck, supra note 37, at 638. 
under section 5(c) thereof. ${ }^{45}$

Our present situation in Lebanon ${ }^{\mathbf{4}}$ underscores both the advisability of the amendments I have just described and the valuable contribution the War Powers Resolution, once invoked, can make toward achieving a considered national policy. Although the bulk of our ground forces are in the process of being withdrawn from their compound to ships standing offshore, they have been-and air and naval units may continue to be- embroiled in an internecine struggle among the many ethnic and religious groups that have been warring in Lebanon from time out of memory. The deployments in Lebanon were ordered by the President on his authority as Commander-in-Chief. They were not the subject of meaningful consultation with Congress under section 3 of the War Powers Resolution. As the commentators have noted, if ever troops were about to be introduced into "hostilities" or into a "situation where imminent involvement in hostilities is clearly indicated by the circumstances," Lebanon was the case. And yet there was no consultation.

Although the President did not consult with Congress before deploying troops in Lebanon, he did at various times report to Congress after the fact. After dispatching 800 Marines to Lebanon as part of a multilateral peacekeeping force introduced in connection with the withdrawal of P.L.O. forces from Beirut, the President filed a report with Congress that described itself as "consistent with the War Powers Resolution" rather than in "compliance with" its reporting requirements." The President subsequently deployed an additional 1,200 Marines "to facilitate the restoration of Lebanese Government sovereignty and authority" and again reported to Congress on that deployment "consistent with" the War Powers Resolution, but without acknowledging directly his obligation to report. ${ }^{48} \mathrm{~A}$ third such report was submitted to Congress after our forces sustained their first combat fatalities in Lebanon.

48 The essential concept of an anticipatory cut-off of funds is embodied in a proposed amendment to the War Powers Resolution, introduced on September 29, 1983, by Senators Granston, Eagleton, and Stennis. See S. 1906, 98th Cong., 1st Sess., 129 CONG. REC. 12,345 (1983). This amendment, however, would also withhold funds from any presidential use of force outside of four enumerated categories of action proposed by the sponsors as the limit of the President's constitutional war powers. See also Franck, supra note 37, at 639.

\$8 Since Mr. Vance delivered this speech all U.S. forces have been withdrawn from Lebanese soil. See New York Times, Feb. 27, 1984, \& A, at 1, col. 6.

47 See Report dated Aug. 24, 1982, from President Ronald Reagan to Hon. Thomas P. O'Neill, Speaker of the House of Representatives, reprinied in WAR Power Documents, supra note 37, at 60 (emphasis added).

18 See Report dated Sept. 29, 1982 from President Ronald Reagan to Hon. Thomas P. O'Neill, Speaker of the House of Representatives, reprinted in WAR Power Documents, supra note 37, at 62 . 
That report, again, was submitted "consistent with" the War Powers Resolution rather than in compliance with it."

Acting on information gained in those reports, Congress determined that our forces had been introduced into "hostilities" in Lebanon and that the sixty or ninety-day time limit on our continued involvement there under the War Powers Resolution had begun to run on the day on which our first combat deaths occurred. ${ }^{\mathbf{B 0}}$ Faced with that constraint on deployment of our forces, the administration negotiated with Congress for an express authorization for deployment beyond the sixty or ninety-day period. Congress and the President finally agreed on a measure authorizing deployment for an additional eighteen months, but subject to a variety of important conditions and restrictions designed to define and limit the scope of our involvement in the Lebanese conflict. ${ }^{51}$

In this case, the War Powers Resolution has belatedly achieved its purpose by bringing the President and the Congress together to discuss a critically important foreign policy issue that in my judgment should have been thrashed out before the deployments were made. I trust that we will see increasing congressional participation in future decisions relating to deployments of troops overseas. But if the past is any indication of the future, it is likely that unless the War Powers Resolution is strengthened, future Presidents of both parties will only reluctantly exercise the necessary "collective judgment" with Congress.

19 Report dated Aug. 30, 1983 from President Ronald Reagan to Hon. Thomas P. O'Neill, Speaker of the House of Representatives, reprinted in WAR PoWER DocuMENTS, supra note 37, at 65 .

${ }^{80}$ See Multinational Force in Lebanon Resolution, Pub. L. No. 98-119, 97 Stat. 805 (1983).

s1 See id. 


$$
\text { - }
$$

